\title{
EFFECTIVE ASR INHIBITING LENGTH AND APPLIED ELECTRICAL FIELD UNDER ACCELERATED LITHIUM MIGRATION TECHNIQUE
}

Wei-Chien Wang

Department of Civil Engineering, Chung Yuan Christian University, ChungLi, Taiwan, R.O.C., weichien@cycu.edu.tw

Chih-Chien Liu

Department of Civil Engineering, ROC Military Academy, Fengshan, Taiwan, R.O.C.

Chau Lee

Department of Civil Engineering, National Central University, ChungLi, Taiwan, R.O.C.

Follow this and additional works at: https://jmstt.ntou.edu.tw/journal

Part of the Civil and Environmental Engineering Commons

\section{Recommended Citation}

Wang, Wei-Chien; Liu, Chih-Chien; and Lee, Chau (2012) "EFFECTIVE ASR INHIBITING LENGTH AND APPLIED ELECTRICAL FIELD UNDER ACCELERATED LITHIUM MIGRATION TECHNIQUE," Journal of Marine Science and Technology. Vol. 20: Iss. 3, Article 1.

DOI: $10.51400 / 2709-6998.1800$

Available at: https://jmstt.ntou.edu.tw/journal/vol20/iss3/1

This Research Article is brought to you for free and open access by Journal of Marine Science and Technology. It has been accepted for inclusion in Journal of Marine Science and Technology by an authorized editor of Journal of Marine Science and Technology. 


\title{
EFFECTIVE ASR INHIBITING LENGTH AND APPLIED ELECTRICAL FIELD UNDER ACCELERATED LITHIUM MIGRATION TECHNIQUE
}

\author{
Wei-Chien Wang ${ }^{1}$, Chih-Chien $\mathrm{Liu}^{2}$, and Chau Lee ${ }^{3}$
}

Key words: electrochemical technique, alkali-silica reaction, lithium, migration.

\begin{abstract}
This study investigates the effective concrete length and electric field strength during Accelerated Lithium Migration Technique (ALMT) application for the inhibition of the alkali-silica reaction (ASR). Concrete specimens measuring 10 $\mathrm{cm}$ in diameter and 5, 7, 9, 11, 14, 17, 20 and $23 \mathrm{~cm}$ in length are fabricated. Specimens with 5, 7, and $9 \mathrm{~cm}$ in length are applied $9 \mathrm{~A} / \mathrm{m}^{2}$ constant current density, and the rest specimens are applied $60 \mathrm{~V}$ constant voltage. After the ALMT process, the specimen is cut every $0.5 \mathrm{~cm}$ and analyzed its cation content. Experimental results shows that if the aim of ASR inhibition is to reduce the cement alkali content to below $0.6 \%$ and to restrict the upper limit of the applied voltage to $60 \mathrm{~V}$, the lowest effective current density is approximately $3.96 \mathrm{~A} / \mathrm{m}^{2}$, with a treatment length of $15.75 \mathrm{~cm}$, over about 70 days.
\end{abstract}

\section{INTRODUCTION}

The concept of sending $\mathrm{Li}^{+}$into concrete to inhibit ASR using electrochemical technology was first proposed by Page [8] in 1992. In 1996, Stokes [9] attempted to add lithium compounds into an electrolyte, thus providing proof that an electric field could be used to send $\mathrm{Li}^{+}$into concrete. In 2000 , Whitmore and Abbott [12] applied this technique to structures in the field. In May of 2006, two columns in Houston, Texas were chosen for the study of the electrochemical treatment of

Paper submitted 01/19/11; revised 06/05/11; accepted 09/01/11. Author for correspondence: Wei-Chien Wang (e-mail:weichien@cycu.edu.tw).

${ }^{I}$ Department of Civil Engineering, Chung Yuan Christian University, ChungLi, Taiwan, R.O.C.

${ }^{2}$ Department of Civil Engineering, ROC Military Academy, Fengshan, Taiwan, R.O.C.

${ }^{3}$ Department of Civil Engineering, National Central University, ChungLi, Taiwan, R.O.C. the alkali-silica reaction (ASR). By using the reinforced steel as the cathode, it was found that a sufficient quantity of $\mathrm{Li}^{+}$ could be delivered up to $50 \mathrm{~mm}$ in the reinforced steel, which was more effective than other methods, such as soaking, spraying or vacuum. However, the area surrounding the reinforced steel still had the potential ASR problems of $\mathrm{Na}^{+}$and $\mathrm{K}^{+}$concentrations and an increase in $\mathrm{OH}^{-}$concentration $[3,7]$.

The Accelerated Lithium Migration Technique (ACMT) utilizes electrical property to prevent ASR in concrete was conceptualized by Professor Lee in 1998, whereby anions migrate toward the anode and cations migrate toward the cathode, to remove the $\mathrm{Na}^{+}$and $\mathrm{K}^{+}$ions from inside the concrete and migrate $\mathrm{Li}^{+}$into the concrete, simultaneously. $\mathrm{Na}^{+}$ and $\mathrm{K}^{+}$can cause ASR and $\mathrm{Li}^{+}$can prevent ASR in concrete. After experimentation, it was shown that this method effectively inhibited ASR $[2,6]$.

This study was to investigate the effects of specimen length on ASR-related cation migration during the use of ALMT. This study took the ACI mixed design, using the ASTM C1293 aggregate gradation as the basis, to analyze the effective length and lowest electric field strength required to inhibit ASR using ALMT, thus providing practical operational and design references for ALMT.

\section{EXPERIMENT}

\section{Materials Used and Specimen Fabrication}

ASTM Type I Portland cement was used, with $\mathrm{Na}_{2} \mathrm{O}_{\text {eq }}$ as $0.50 \%\left(\mathrm{Na}_{2} \mathrm{O}\right.$ and $\mathrm{K}_{2} \mathrm{O}$ were $0.11 \%$ and $0.59 \%$, respectively). Meta sandstone from Eastern Taiwan was used for the aggregate. The 14-day expansion was $0.033 \%$ for the ASTM C1260 test, and the 3-month expansion was $0.068 \%$ for the ASTM C227 test. The above results and the ASTM C289 test result determined that this aggregate had potential ASR reactivity.

The concrete cylinder specimens $(\phi 10 \times 25 \mathrm{~cm})$ were fabricated according to the ACI mixed design, and cement, coarse aggregate and fine aggregate were used as 460, 838 and 769 $\mathrm{kg} / \mathrm{m}^{3}$, respectively. The water/cement ratio was 0.5 , with the same coarse and fine aggregate gradations as for the ASTM 


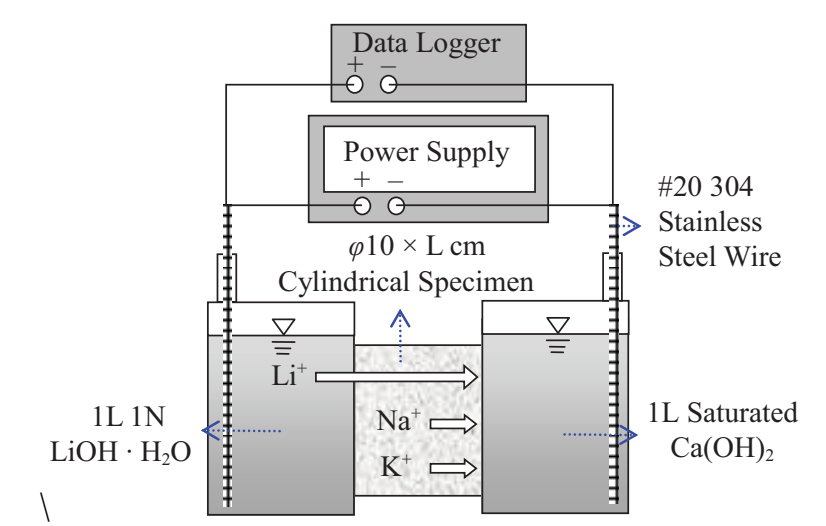

Fig. 1. ALMT schematic diagram (using applied constant current density as example).

C1293 specification. $\mathrm{NaOH}$ was used to adjust the alkali content to $2.0 \% \mathrm{Na}_{2} \mathrm{O}_{\text {eq. }}$. The specimens were cured in a $23^{\circ} \mathrm{C}$, $100 \%$ R.H. environment for 3 months.

\section{ALMT Test Module and Experimental Procedure}

Fig. 1 shows the ALMT schematic diagram for applying a constant current density $[2,6]$. Only the necessary exhaust openings were kept during the electrolysis process to prevent air dissolving into the electrolyte and increasing the resistance [13]. A data logger was used to record changes in voltage or current, an ion chromatograph (IC) was used to analyze the cation concentration inside the cathode electrolyte, periodically, while the temperature changes within the cathodic cell were measured manually.

Specimens with a length of 5, 7, 9, 11, 14, 17, 20 and $23 \mathrm{~cm}$ were cut from the center region of the cured concrete. After vacuum saturation treatment, based on the ASTM C1202 preprocessing procedure, the ALMT experiment was underway. The applied voltage for the practical application of electrochemical chloride extraction (ECE) normally does not exceed $40 \mathrm{~V}$ and 8 weeks [7]. In order to observe the migration behavior of ions during the electrolysis process, a single electric supply source with $60 \mathrm{~V}$ as the upper limit was used as the boundary electric field. For specimens with $5-9 \mathrm{~cm}$, a constant current density of $9 \mathrm{~A} / \mathrm{m}^{2}$ was applied. For the rest of the longer specimens, before the applied current density reached $9 \mathrm{~A} / \mathrm{m}^{2}$, the voltage had already exceeded $60 \mathrm{~V}$, therefore, undergoing the $60 \mathrm{~V}$ constant voltage experiment. The experimental numbers were L5C, L7C, L9C, L11 V, L14V, L17V, L20V and L23V, respectively. Experiments L5C-L11V went through electrolysis for 2 months. For the rest of the experiments, since the currents were smaller, the electrolysis lasted 4 months, with each experimental value representing the average of two experimental results. After electrolysis was completed, the specimens underwent dry cutting every $5 \mathrm{~mm}$ from the anodic cell to the cathodic cell. The soluble ions were stripped according to the AASHTO T260 experimental process, and the free-state cations within the specimen were analyzed using an IC.

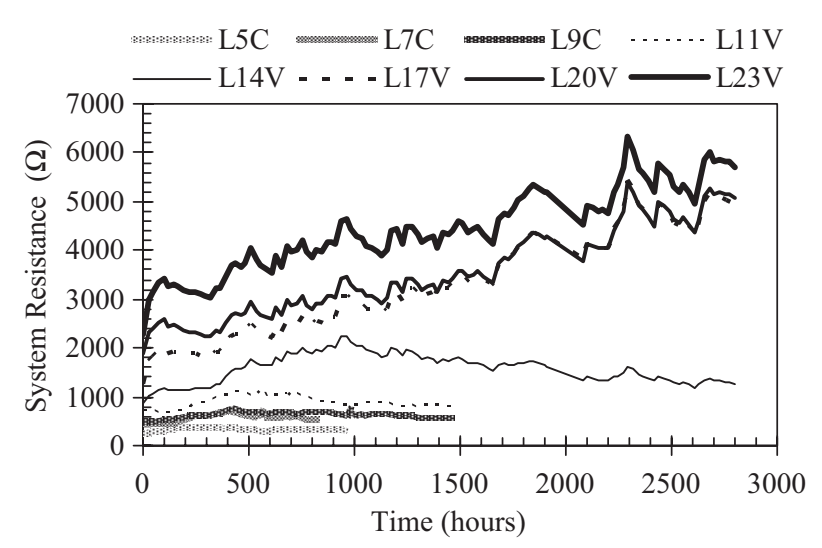

Fig. 2. System resistance during the duration of electrolysis.

\section{RESULTS AND DISCUSSION}

\section{Temperature and System Resistance}

The average temperature of the experiment was $0.8-2.4^{\circ} \mathrm{C}$ above room temperature, indicating that when the electric field strength was maintained at under $60 \mathrm{~V}$, the specimen temperature did not rise excessively. Therefore, the increased temperature did not significantly affect ion migration. With the applied voltage/current defined as system resistance, as shown in Fig. 2, it was found that the system resistance for specimens with a length of 5-14 cm remained relatively stable during electrolysis, while the system resistance for specimens measuring $17-23 \mathrm{~cm}$ in length was $45-284 \%$ greater towards the end of the ALMT process as compared to their initial value.

Assuming that concrete is a homogeneous material with its resistance obeying Ohm's Law, then, in theory, its resistance should be proportional to the length of the fixed crosssectional specimen. By dividing the specimen lengths from Experiments L5C, L7C, L9C, L11V, L14V, L17V, L20V and L23V by the specimen length from Experiment L5C, the obtained normalized theoretical resistance values were 1.0, 1.4, 1.8, 2.2, 2.8, 3.4, 4.0 and 4.6, respectively, as shown in Fig. 3.

As shown in Fig. 3, it was found that when the specimen length increased, the experimental normalized initial and average system resistances were larger than the theoretical values. The trend line equation gives $R_{i} / R_{i, 0}=0.1175 L^{1.3433}$ and $R_{a} / R_{a, 0}=0.0546 L^{1.7363}$, respectively, indicating that with the increase in specimen length, the range by which the experimental value was larger than the theoretical value also increased. The reason for this might have been due to the fact that the increase in specimen length greatly decreased the connectivity of pore percolation. Using $23 \mathrm{~cm}$ as an example, the experimental normalized initial and average system resistance values were about 7.9 and 12.6, which were 1.7 and 2.7 times the theoretical normalized values.

\section{Changes in Cation Concentration Inside the Catholyte}

In order to compare the changes in cation concentration 
Table 1. Results from $\mathrm{Na}^{+}$and $\mathrm{K}^{+}$concentration-accumulated charge curves in the catholyte.

\begin{tabular}{|c|c|c|c|c|c|c|c|c|c|}
\hline \multirow[t]{2}{*}{ No. } & \multicolumn{2}{|c|}{$\begin{array}{l}\text { Migrated ions per unit charge } \\
\left(\times 10^{-6} \mathrm{~mole} / \mathrm{C}\right)\end{array}$} & \multicolumn{2}{|c|}{ Removal completion time (h) } & \multicolumn{2}{|c|}{$\begin{array}{c}\text { Removed ions } \\
\left(\times 10^{-3} \text { mole }\right)\end{array}$} & \multicolumn{2}{|c|}{$\begin{array}{c}\text { Removal } \\
\text { percentage }\end{array}$} & \multirow{2}{*}{$\begin{array}{c}\text { Alkali removal } \\
\text { percentage }\end{array}$} \\
\hline & $\mathrm{C}_{\mathrm{Na}}$ & $\mathrm{C}_{\mathrm{K}}$ & $\mathrm{t}_{\mathrm{Na}}$ & $t_{K}$ & $\mathrm{Na}^{+}$ & $\mathrm{K}^{+}$ & $\mathrm{Na}^{+}$ & $\mathrm{K}^{+}$ & \\
\hline L5C & 1.221 & 0.320 & 284.2 & 208.7 & 85.6 & 15.9 & 95.6 & 72.3 & 91.0 \\
\hline L7C & 1.221 & 0.314 & 403.3 & 302.3 & 121.1 & 25.1 & 92.2 & 79.0 & 89.6 \\
\hline L9C & 1.198 & 0.307 & 483.5 & 340.3 & 144.8 & 27.8 & 87.0 & 86.6 & 87.0 \\
\hline L11V & 1.168 & 0.297 & 773.6 & 581.1 & 179.6 & 38.3 & 87.0 & 78.5 & 85.0 \\
\hline L14V & 1.123 & 0.269 & 1366.6 & 1460.7 & 218.4 & 53.7 & 83.2 & 84.5 & 83.4 \\
\hline L17V & 1.087 & 0.259 & 1613.3 & 1775.3 & 155.2 & 41.5 & 48.7 & 53.7 & 49.6 \\
\hline L20V & 1.081 & 0.247 & 1646.1 & 1481.4 & 135.1 & 28.1 & 36.0 & 30.9 & 35.0 \\
\hline $\mathrm{L} 23 \mathrm{~V}$ & 1.075 & 0.245 & 1489.5 & 1794.4 & 94.7 & 25.7 & 22.0 & 24.6 & 22.5 \\
\hline
\end{tabular}

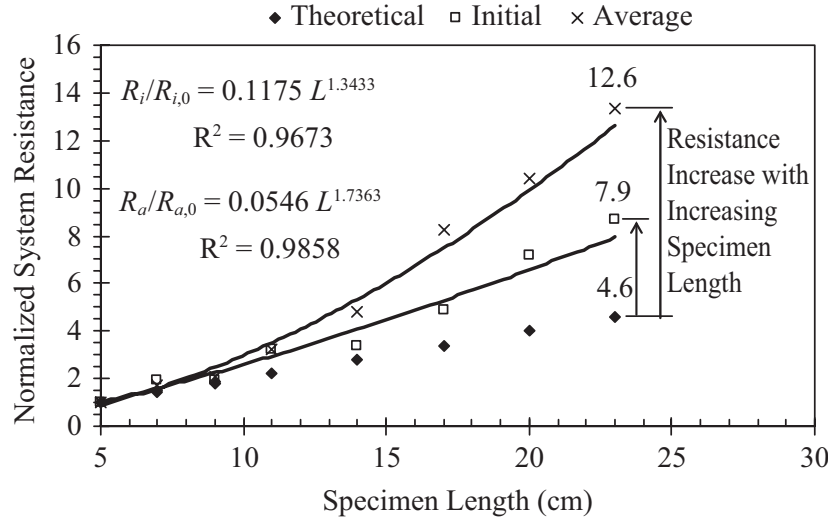

Fig. 3. Relationship between normalized system resistance and specimen length.

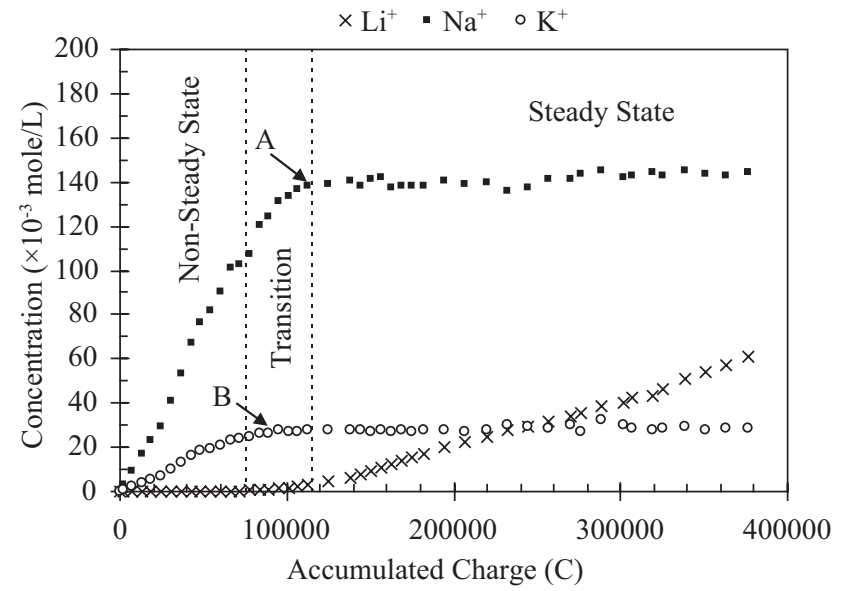

Fig. 4. Typical curve between cation concentration inside the catholyte and the accumulated charge (using L9C as an example).

within the catholyte under the constant current density and the constant voltage model, as shown in Fig. 4 (using Experiment L9C as an example), the typical relationship between the catholytel cation concentration and the accumulated electric charge was constructed. It was found that with the increase in

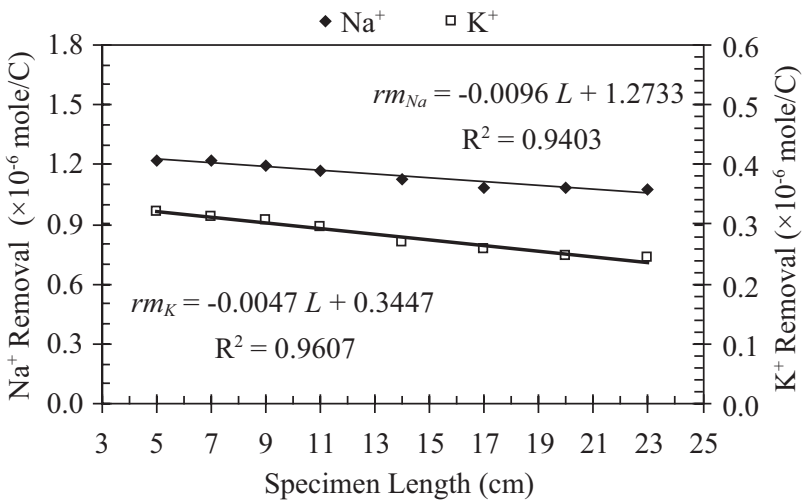

Fig. 5. Relationship between $\mathrm{Na}^{+}$and $\mathrm{K}^{+}$removal amount per unit charge during steady migration $\left(r m_{N a}\right.$ and $\left.r m_{K}\right)$ and specimen length.

accumulated electric charge, $\mathrm{Na}^{+}$and $\mathrm{K}^{+}$migration could be separated into two stages: steady migration and migration completion, and that the accumulated electric charge for migration completion for $\mathrm{K}^{+}$was less than that for $\mathrm{Na}^{+}$, as shown in points $\mathrm{A}$ and $\mathrm{B}$, respectively. The $\mathrm{Li}^{+}$migration period could be separated into the three stages: non-steady state, transitional state, and steady state.

\section{Migration Behavior of $\mathrm{Na}^{+}$and $\mathrm{K}^{+}$}

The results are listed in Table 1. Fig. 5 shows that, during the steady migration stage, there was a good linear relationship between the $\mathrm{Na}^{+}$and $\mathrm{K}^{+}$removal amount per unit charge $\left(\mathrm{rm}_{\mathrm{Na}}\right.$ and $\left.r m_{K}\right)$ and the specimen length $(L)$. The $\mathrm{Na}^{+}$and $\mathrm{K}^{+}$removal amount per unit charge decreased with increases in specimen length, with the linear regression equation giving $r m_{N a}=-0.0096 L+1.2733$ and $r m_{K}=-0.0047 L+0.3447$. From the slope of the equation, it was found that for each $1 \mathrm{~cm}$ increase in electrode distance, the $\mathrm{Na}^{+}$and $\mathrm{K}^{+}$removal amount per unit charge decreased by $9.6 \times 10^{-9}$ and $4.7 \times 10^{-9}$ mole, respectively.

Fig. 6 shows the relationship between the $\mathrm{Na}^{+}$and $\mathrm{K}^{+}$removal amount per unit charge $\left(r m_{N a}\right.$ and $\left.r m_{K}\right)$ and average 


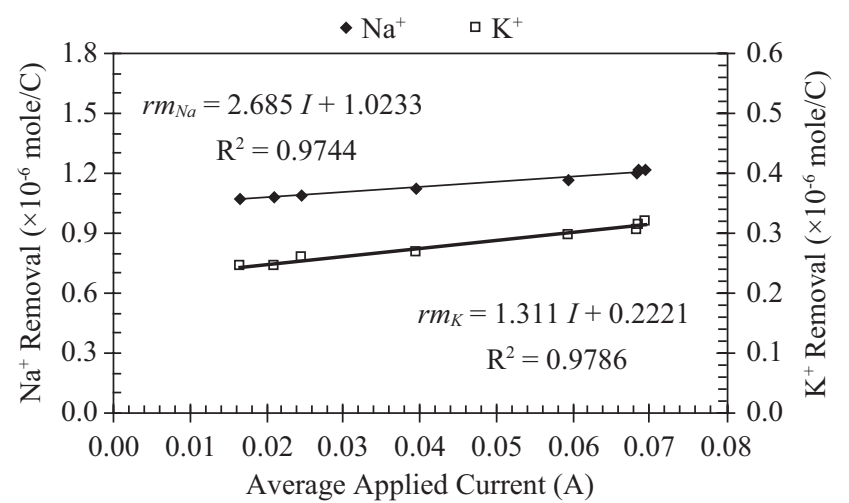

Fig. 6. Relationship between $\mathrm{Na}^{+}$and $\mathrm{K}^{+}$removal amount per unit charge during steady migration $\left(r m_{N a}\right.$ and $\left.r m_{K}\right)$ and average applied current $(I)$.

current $(I)$, showing that there was a good linear relationship between the two. The linear regression equation gives $r m_{N a}=$ $2.685 I+1.0233$ and $r m_{K}=1.311 I+0.2221$. From the slope of the equation, it was found that for each $1 \mathrm{~A}$ increase in average current during the alkaline removal stage, the $\mathrm{Na}^{+}$and $\mathrm{K}^{+}$removal amount per unit charge increased by $2.685 \times 10^{-6}$ and $1.311 \times 10^{-6}$ mole, respectively.

As discussed above, it could be seen that with an increase in the specimen length, the concrete resistance was larger than the values calculated using Ohm's law; whereas reducing the applied current during constant voltage reduced the $\mathrm{Na}^{+}$and $\mathrm{K}^{+}$removal amount per unit charge. Furthermore, the applied current decreased with increases in specimen length, and the removable alkali content percentage of the specimen was also reduced. As shown in Fig. 7, it was found that there was a sharp decrease in removable alkali content percentage after the specimen length exceeded $14 \mathrm{~cm}$. Since the designed cement alkali content was $2.0 \% \mathrm{Na}_{2} \mathrm{O}_{\text {eq }}$, if the goal of ASR inhibition was to reduce the cement alkali content to below $0.6 \%$, then $70 \%$ of the alkali content should be removed. From the experimental result trendline for $17-23 \mathrm{~cm}$ in the figure, the lowest effective applied current density of $3.96 \mathrm{~A} / \mathrm{m}^{2}$ was arrived at by calculating the required applied current as 0.0311 A, divided by the specimen cross-sectional area. The effective treatment length was arrived at by finding the corresponding specimen length for 0.0311 A from the specimen lengthapplied current curve of the constant voltage experiment, which was around $15.75 \mathrm{~cm}$, as shown in Fig. 7. As shown in Fig. 6, the $\mathrm{Na}^{+}$and $\mathrm{K}^{+}$removal amount per unit charge, when $0.0311 \mathrm{~A}$ was applied, were calculated to be $1.10 \times 10^{-6}$ and $2.63 \times 10^{-7} \mathrm{~mole} / \mathrm{C}$, respectively; while for the specimen with a length of $15.75 \mathrm{~cm}$, the $\mathrm{Na}^{+}$and $\mathrm{K}^{+}$contents were 295.50 and $71.55 \times 10^{-3}$ mole, respectively, with the removal of $70 \%$ requiring about 70.0 and 70.9 days. Furthermore, with an applied current of over $0.04 \mathrm{~A}$, which was $5.10 \mathrm{~A} / \mathrm{m}^{2}$, over $83 \%$ of the alkali content was removed. Even when the current density was increased further, there was only a limited increase in the removal of the alkali content.

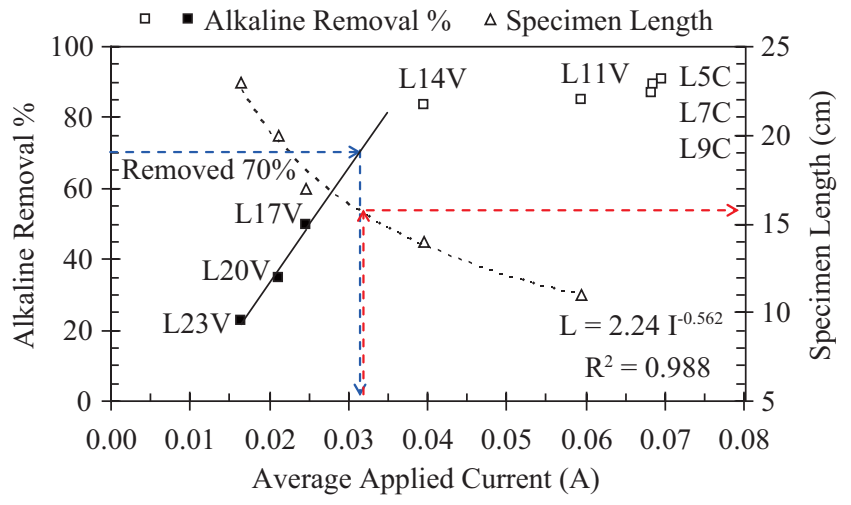

Fig. 7. Relationship among alkaline removal percentage during steady migration, the specimen length and average applied current.

\section{Migration Behavior of $\mathrm{Li}^{+}$}

\section{1) Non-Steady State}

During the ALMT experiment process, the non-steady-state migration coefficient $D_{n}\left(\mathrm{~m}^{2} / \mathrm{s}\right)$ of $\mathrm{Li}^{+}$was obtained through the modified Fick's Second Law [10, 14]:

$$
\frac{d C}{d t}=D_{n}\left(\frac{d^{2} C}{d x^{2}}-\frac{|z| F E}{R T} \frac{d C}{d x}\right)
$$

where $C$ is the ion concentration (mole/L), which is a function of time, $t(\mathrm{sec})$, and distance, $x(\mathrm{~m}) ; z$ is the electrical charge of $\mathrm{Li}^{+} ; F$ is the Faraday constant $(96500 \mathrm{C} /$ mole $) ; E$ is the strength of the electric field $(\mathrm{V} / \mathrm{m}) ; R$ is the universal gas constant $(8.3 \mathrm{~J} / \mathrm{mole} / \mathrm{K})$; and $T$ is the absolute temperature $(\mathrm{K})$. Initial condition: for $x>0$ and $t=0, C=0$; boundary condition: for $x=0$ and $t>0, C=C_{0}$; for $x=\infty$ and $t=$ large, $C=0$. The analytical solution of Eq. (1) is:

$$
C(x, t)=\frac{C_{0}}{2}\left[e^{a x} \operatorname{erfc}\left(\frac{x+a D_{n} t}{2 \sqrt{D_{n} t}}\right)+\operatorname{erfc}\left(\frac{x-a D_{n} t}{2 \sqrt{D_{n} t}}\right)\right]
$$

where $a=\frac{|z| F E}{R T}, C_{0}$ is the $\mathrm{Li}^{+}$concentration inside the anodic cell (mole/L), and erfc is the complementary error function.

From Eq. (2), $D_{n}$ can be calculated to be [10]:

$$
D_{n}=\frac{1}{a}\left[\frac{x-\alpha \sqrt{x}}{t}\right]
$$

where $\alpha=2 \sqrt{\frac{1}{a}} \operatorname{erf}^{-1}\left(1-\frac{2 C}{C_{0}}\right)$, and $\operatorname{erf}^{-1}$ is the inverse of the error function. 
Table $2 . \mathrm{Li}^{+}$non-steady-state and steady-state migration coefficients.

\begin{tabular}{cccccccc}
\hline \hline No. & \multicolumn{3}{c}{ Non-steady state } & \multicolumn{2}{c}{ Steady state } \\
\cline { 2 - 8 } & $\begin{array}{c}\text { Average current } \\
(\mathrm{A})\end{array}$ & $\begin{array}{c}Q_{0.1} \\
(\mathrm{C})\end{array}$ & $\begin{array}{c}t_{0.1} \\
(\mathrm{~h})\end{array}$ & $\begin{array}{c}D_{n} \\
\left(\times 10^{-12} \mathrm{~m}^{2} / \mathrm{s}\right)\end{array}$ & $\begin{array}{c}\text { Average current } \\
(\mathrm{A})\end{array}$ & $\begin{array}{c}\mathrm{Li}^{+} \text {removal per unit charge } k \\
\left(\times 10^{-7} \mathrm{~mole} / \mathrm{C}\right)\end{array}$ & $\begin{array}{c}D_{s} \\
\left(\times 10^{-13} \mathrm{~m}^{2} / \mathrm{s}\right)\end{array}$ \\
\hline \hline L5C & 0.070 & 44366 & 184 & 4.03 & 0.068 & 3.195 & 1.638 \\
\hline L7C & 0.069 & 57409 & 217 & 2.17 & 0.069 & 3.331 & 3.160 \\
L9C & 0.068 & 77791 & 329 & 1.19 & 0.070 & 2.980 & 0.764 \\
\hline \hline L11V & 0.058 & 102443 & 516 & 0.53 & 0.059 & 0.990 & 0.106 \\
\hline L14V & 0.040 & 140611 & 1028 & 0.26 & 0.040 & 0.970 & 0.046 \\
\hline L17V & 0.023 & 176067 & 1956 & 0.14 & 0.023 & 0.070 & 0.003 \\
\hline L20V & 0.018 & 208885 & 2720 & 0.10 & 0.018 & - & - \\
\hline L23V & - & - & - & - & - &
\end{tabular}

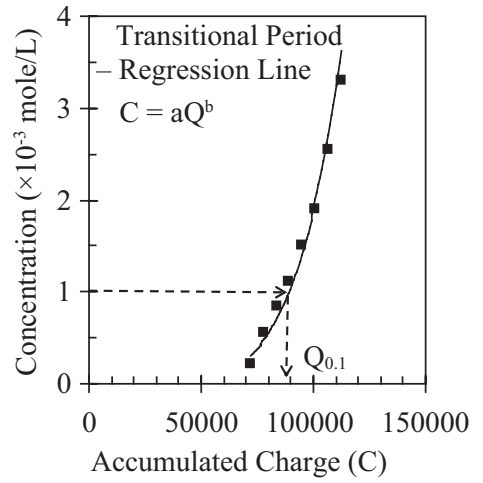

(a)

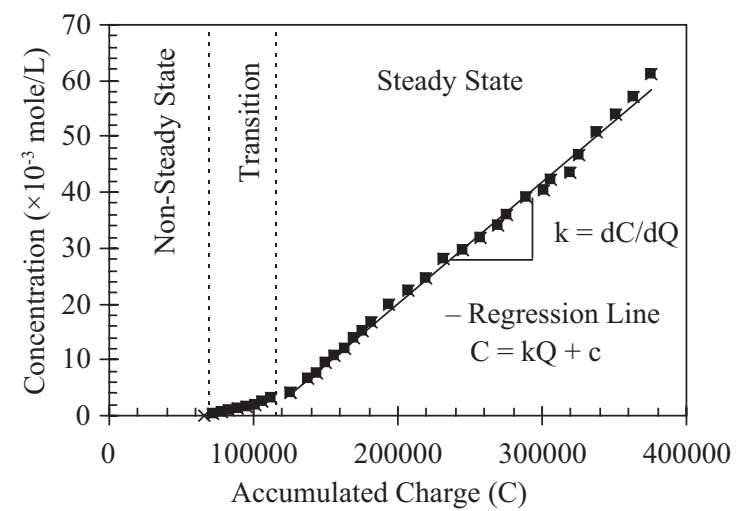

(b)

Fig. 8. Changes of $\mathrm{Li}^{+}$concentration in the catholyte (using Experiment L9C as an example).

Since the experimental process did not continuously measure the ion concentration inside the electrolyte, it was not easy to obtain the accurate time $\mathrm{Li}^{+}$took to pass through the specimen. Therefore, as shown in Fig. 8(a), the $\mathrm{Li}^{+}$concentration-accumulated charge regression curve for the transitional period was first calculated as in Eq. (4), then the corresponding accumulated charge $\left(Q_{0.1}\right)$ was calculated for $C / C_{0}=0.1 \%\left(C / C_{0}\right.$, cathodic cell $\mathrm{Li}^{+}$concentration/anodic cell $\mathrm{Li}^{+}$concentration); then it was divided by the average current to obtain $t_{0.1}$ as the required time for $\mathrm{Li}^{+}$to traverse the specimen: [11]

$$
C=\mathrm{a} Q^{\mathrm{b}}, \quad \text { Transitional Peiord }
$$

where $C$ is the $\mathrm{Li}^{+}$concentration inside the cathodic cell (mole/L), $Q$ is the accumulated charge $(\mathrm{C})$, a and $\mathrm{b}$ are experimental constants.

The experimental non-steady state average currents, $Q_{0.1}$, $t_{0.1}$ and $D_{n}$, are listed in Table 2. Since $\mathrm{Li}^{+}$was still not able to pass through the specimen after 4 months of electrolysis for Experiment L23V, these experimental values were unavailable. For experiments L11V-L20V, with a constant applied voltage of $60 \mathrm{~V}$, the non-steady state average current decreased with increases in specimen length. For all experiments, the cumulative applied charge $\left(Q_{0.1}\right)$ required to reach $C / C_{0}=0.1 \%$ increased with the increase of specimen length $(L)$. Fig. 9 shows that the rate of increase in the time it took for $\mathrm{Li}^{+}$to pass through the specimen $t_{0.1}$ increased with the increase in specimen length, but the rate of decrease of the non-steady state migration coefficient $D_{n}$ decreased with the increase in specimen length. The first derivatives of the regression equation, $\frac{d t_{0.1}}{d L}=12.08 e^{0.1947 L}>1$ and $\frac{d D_{n}}{d L}=-\frac{1338}{L^{3.83}}<1$, both proved that the increase in specimen length was not advantageous to the migration of $\mathrm{Li}^{+}$.

\section{2) Steady State}

The ions migrating inside the electrolyte are under the influence of the electric field, and the general conversion of mass equation is the Nernst-Planck Equation [5]:

$$
J(x)=D_{j} \frac{\partial C_{j}}{d x}+\frac{Z_{j} F}{R T} D_{j} C_{j} \frac{\partial E_{x}}{d x}+C V
$$

where $J(x)$ is the one-dimensional flow rate of ions (mole $/ \mathrm{m}^{2} / \mathrm{s}$ ), $D_{j}$ is the diffusion coefficient of ion $j\left(\mathrm{~m}^{2} / \mathrm{s}\right), \partial C_{j}$ is the concentration variable of ion $j\left(\mathrm{~mole} / \mathrm{m}^{3}\right), \partial x$ is the displacement 


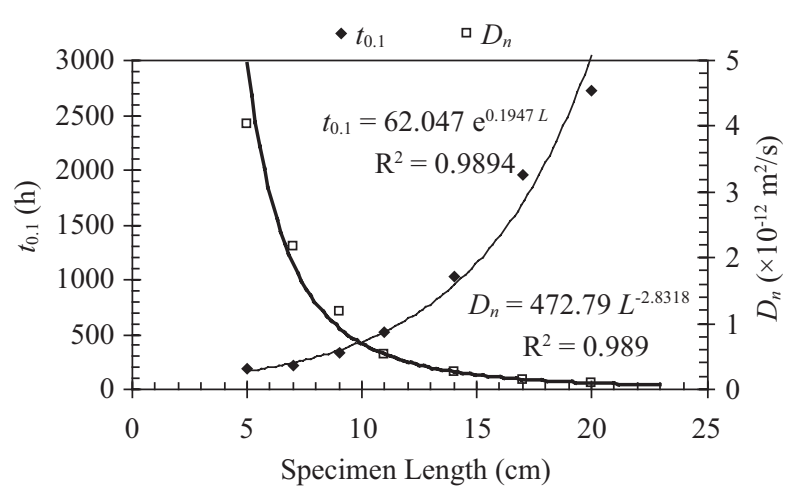

Fig. 9. Relationship between experimental $t_{0.1}$ and $D_{n}$ and specimen length $(L)$.

variable (m), $Z_{j}$ is the electric charge of ion $j, C_{j}$ is the total concentration of ion $j\left(\mathrm{~mole} / \mathrm{m}^{3}\right), \partial E_{x}$ is the potential variable $(\mathrm{V})$, and $V$ is the velocity of the solution $(\mathrm{m} / \mathrm{s})$.

The study of Kropp et al. [5] found that the diffusion generated by the concentration gradient was far smaller than the influence of the electric field and, therefore, could be ignored. If there was no convection during the experiment while calculating the ion flow during steady state, the equation could be simplified to:

$$
J(x)=\frac{Z_{j} F}{R T} D_{j} C \frac{\partial E_{x}}{\partial x}
$$

By transposing Eq. (6), Eq. (7) is obtained:

$$
D_{s}=\frac{J_{s} R T}{z F C_{u p} E}
$$

where $D_{s}$ is the steady state migration coefficient of ions $\left(\mathrm{m}^{2} / \mathrm{s}\right)$, $J_{s}$ is the steady state flux of ions (mole $\left./ \mathrm{m}^{2} / \mathrm{s}\right), x$ is the distance between electrodes $(\mathrm{m}), z$ is the electric charge of ions, $C_{u p}$ is the upstream ion concentration $\left(\mathrm{mole} / \mathrm{m}^{3}\right)$, and $E$ is the strength of the electric field $(\mathrm{V} / \mathrm{m})$. Andrade pointed out that the steady state migration coefficient $\left(D_{s}\right)$ of ions under the influence of a one-dimensional electric field inside concrete materials could be obtained by substituting the experimental result of the steady state flux $\left(J_{s}\right)$ into Eq. $(7)[1,5]$.

From Fig. 8(b), the linear regression equation for the concentration-accumulated charge curve is:

$$
C=k Q+c, \quad \text { Steady state period }
$$

where $k(\mathrm{~mole} / \mathrm{L} / \mathrm{h})$ is the $\mathrm{Li}^{+}$removal rate per unit time, which is the slope of the regression equation; and $c$ is the intercept of the regression equation on the charge axis. The experimental $J_{s}$ can be obtained by $k$ multiplied by the average current and the volume of the cathodic cell, and divided by the specimen cross-section area.

The experimental steady state average currents, $k$ and $D_{s}$ are

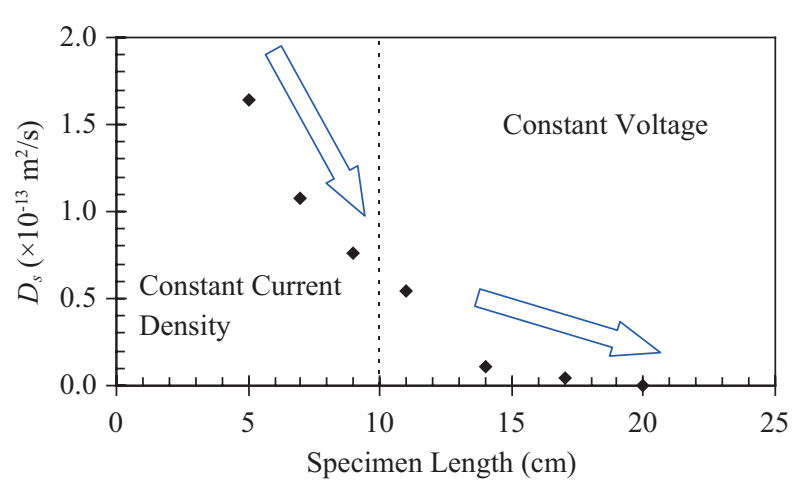

Fig. 10. Relationship between experimental $D_{s}$ and specimen length $(L)$.

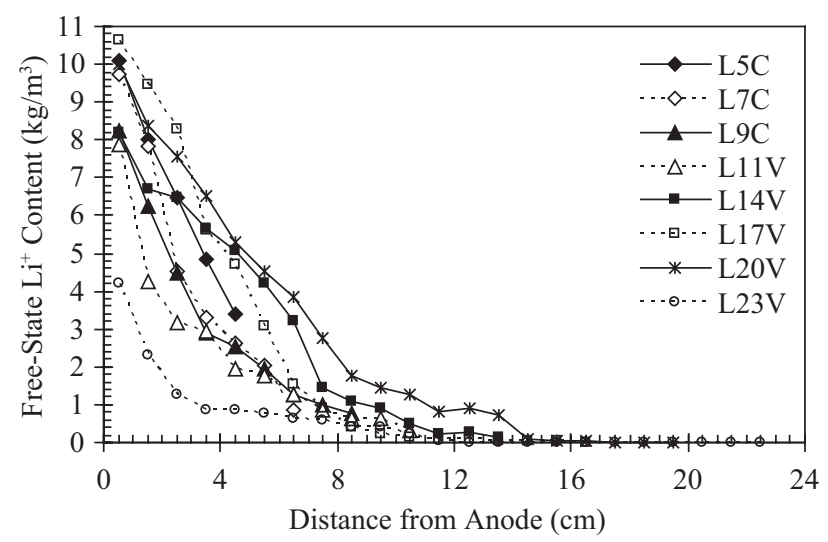

Fig. 11. Free-state $\mathrm{Li}^{+}$content inside specimen after electrolysis.

shown in Table 2. For the constant current density experiments L5C-L9C, there were no significant differences for the steady state average current and k; correspondingly, for the constant voltage experiments L11V-L20V, both the average current and $k$ for the steady state decreased with the increase in specimen length. Fig. 10 shows that the steady state migration coefficient $D_{s}$ had a decreased reduction rate with the increase in specimen length. This result was similar to the relationship between $D_{n}$ and the specimen length.

\section{Free-State Cations inside Specimen after ALMT Process}

Fig. 11 shows the free-state $\mathrm{Li}^{+}$content in the specimen after electrolysis. It was found that the content was highest around the anodic cell, decreasing towards the cathodic cell. When the specimen length was 5, 7, 9, 11 and $14 \mathrm{~cm}$, the average free-state $\mathrm{Li}^{+}$content $0.5 \mathrm{~cm}$ from the cathodic cell was $3.41,0.88,0.78,0.30$ and $0.12 \mathrm{~kg} / \mathrm{m}^{3}$, respectively. When the specimen length increased to 17 and $20 \mathrm{~cm}$, the average free-state $\mathrm{Li}^{+}$content $0.5 \mathrm{~cm}$ from the cathodic cell was already very low, at only 0.001 and $0.0001 \mathrm{~kg} / \mathrm{m}^{3}$. When the specimen length was increased to $23 \mathrm{~cm}$, even with 4 months of electrolysis, only $0.0001 \mathrm{~kg} / \mathrm{m}^{3}$ of free-state $\mathrm{Li}^{+}$could be detected $5.5 \mathrm{~cm}$ from the cathodic cell.

Fig. 12 shows the free-state $\mathrm{Na}^{+}$content in the specimen after electrolysis. When the specimen was 5-14 cm long, the 


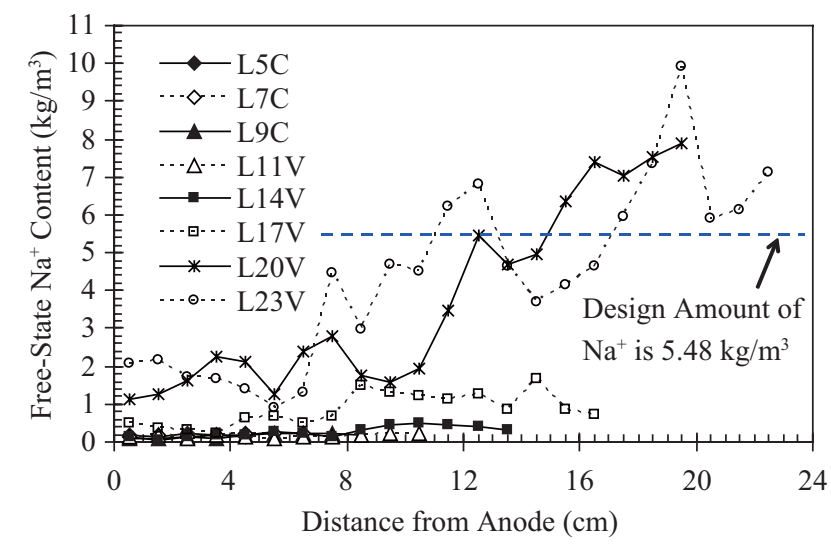

Fig. 12. Free-state $\mathrm{Na}^{+}$content inside specimen after electrolysis.

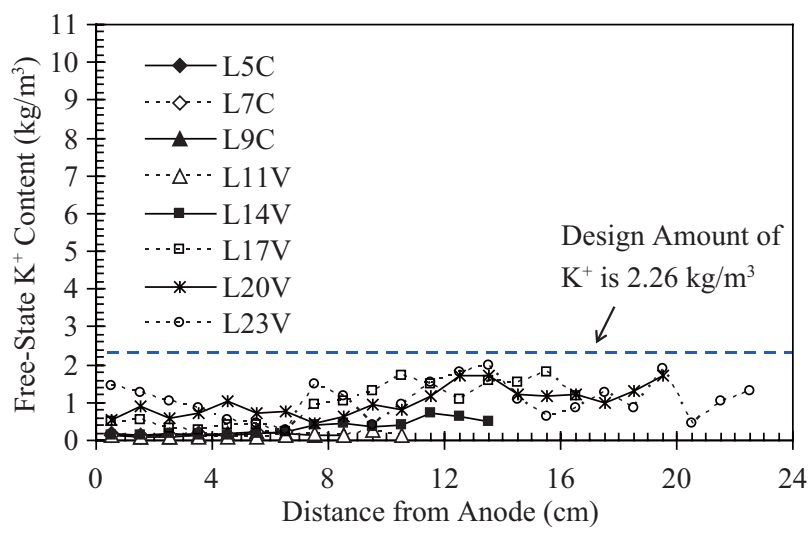

Fig. 13. Free-state $\mathrm{K}^{+}$content inside specimen after electrolysis.

average free-state $\mathrm{Na}^{+}$content in all regions within the specimen was lower than $0.5 \mathrm{~kg} / \mathrm{m}^{3}$, less than $1 / 10$ of the designed total amount of $5.48 \mathrm{~kg} / \mathrm{m}^{3}$. When the specimen length was increased to 20 and $23 \mathrm{~cm}$, the average free-state $\mathrm{Na}^{+}$in all regions could no longer be reduced to below 1.0 $\mathrm{kg} / \mathrm{m}^{3}$. The $\mathrm{Na}^{+}$migrating towards the cathodic cell collected in regions close to the cathodic cell in large amounts, with its free-state content even larger than the designed total amount of $\mathrm{Na}^{+}$. In this way, it worsened the potential ASR problem for the concrete near the cathodic cell.

Fig. 13 shows that the free-state $\mathrm{K}^{+}$content in the specimen after electrolysis increased with the specimen length. The free-state $\mathrm{K}^{+}$content inside the specimen was lower than the designed total amount of $2.26 \mathrm{~kg} / \mathrm{m}^{3}$, but its distribution trend was similar to the free-state $\mathrm{Na}^{+}$content, increasing from the anodic cell towards the cathodic cell.

A study by Hobbs [4] found that when using opal for the manufacturing of cement, when the total alkali content was under $2.0 \mathrm{~kg} / \mathrm{m}^{3}$, there was no sign of expansion. The distribution of free-state $\mathrm{Na}_{2} \mathrm{O}_{\text {eq }}$ after electrolysis is shown in Fig. 14. By using the study of Hobbs as a reference for inhibiting ASR, it was found that for specimens 5-14 cm long, the average free-state alkali content of all interior regions was

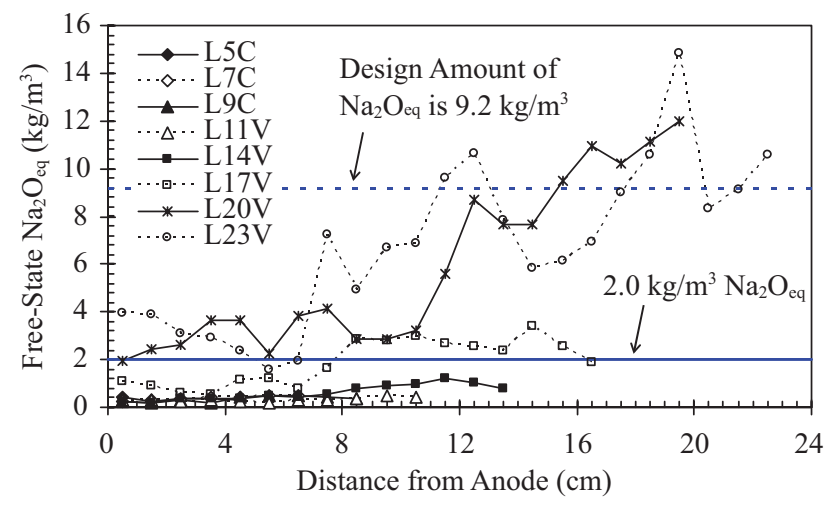

Fig. 14. Free-state $\mathrm{Na}_{2} \mathrm{O}_{\text {eq }}$ content inside specimen after electrolysis.

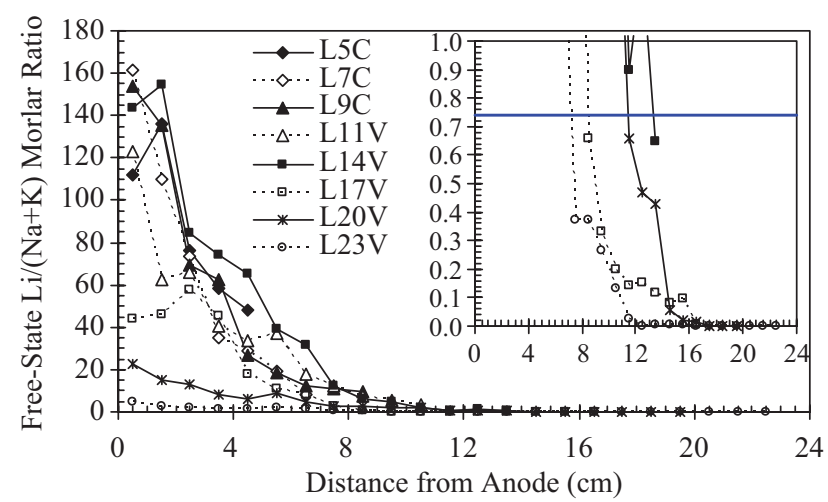

Fig. 15. Free-state $\mathrm{Li} /(\mathrm{Na}+\mathrm{K})$ molar ratio inside specimen after electrolysis.

already lower than $2.0 \mathrm{~kg} / \mathrm{m}^{3}$, thus reaching the goal of inhibiting ASR. When the specimen length was $17 \mathrm{~cm}$, the alkali content between $8.5 \mathrm{~cm}$ from the anode and the cathode already surpassed $2.0 \mathrm{~kg} / \mathrm{m}^{3}$, showing that there was a potential ASR problem. When the length of the specimen increased to $20 \mathrm{~cm}$ and above, it was almost impossible to lower the freestate alkali content within the specimen to below $2.0 \mathrm{~kg} / \mathrm{m}^{3}$, while the free-state alkali content near the cathode of the cement even exceeded the designed total of $9.2 \mathrm{~kg} / \mathrm{m}^{3}$.

For fresh concrete, when the addition of lithium compound was used to inhibit ASR, the lowest effective $\mathrm{Li} / \mathrm{Na}$ molar ratio recommendation was 0.74 [7]. Fig. 15 shows the free-state $\mathrm{Li} /(\mathrm{Na}+\mathrm{K})$ molar ratio distribution inside the specimen after electrolysis; it was found that the value was higher close to the anodic cell and decreased toward the cathodic cell. When the specimen length was $5-11 \mathrm{~cm}$, values within all regions were over 0.74 . When the specimen length was $14 \mathrm{~cm}$, only the values at $0.5 \mathrm{~cm}$ from the cathodic cell were lower than 0.74 ; but, as shown in Fig. 14, the free-state alkali content at that area was only $0.82 \mathrm{Na}_{2} \mathrm{O}_{\text {eq. }}$. From the point of view of reducing the alkali content, this had already satisfied the objective of ASR inhibition. When the specimen length increased to 17, 20 and $23 \mathrm{~cm}$ for the regions $8.5,12.5$ and $7.5 \mathrm{~cm}$ from the anodic cell to the cathodic cell, the free-state $\mathrm{Li} /(\mathrm{Na}+\mathrm{K})$ molar ratio 
did not reach 0.74. At the same time, Fig. 14 shows that the $\mathrm{Na}_{2} \mathrm{O}_{\text {eq }}$ also exceeded $2.0 \mathrm{~kg} / \mathrm{m}^{3}$, and so did not effectively inhibit ASR. Therefore, the results of this analysis corresponded with the aforementioned calculated effective length of $15.75 \mathrm{~cm}$ using ALMT.

\section{CONCLUSIONS}

This study used the ASTM C1293 aggregate gradation, according to the ACI mix design, to fabricate concrete specimens. The following conclusions were reached:

1. With an increase in specimen length, the experimental value of system resistance was higher than the theoretical value arrived at through the use of Ohm's law, and the difference increased with the increase in specimen length.

2. There was a good linear relationship between the $\mathrm{Na}^{+}$and $\mathrm{K}^{+}$removal amount per unit charge and the specimen length, and the removal amount decreased with the increase in specimen length.

3. The rate of increase of the time $\mathrm{Li}^{+}$required to pass through the specimen increased with the increase in specimen length, but the rate of decrease of the non-steady and steady state migration coefficients decreased with the increase of specimen length.

4. Taking the goal of ASR inhibition of reducing the cement alkali content to below $0.6 \%$, the lowest effective applied current density was $3.96 \mathrm{~A} / \mathrm{m}^{2}$, and the effective treatment length was about $15.75 \mathrm{~cm}$, taking about 70 days.

5. After the completion of the ALMT experiment, for specimens measuring $5-14 \mathrm{~cm}$ in length, the internal free-state alkali content were all below $2.0 \mathrm{~kg} / \mathrm{m}^{3}$ already, with the $\mathrm{Li} /(\mathrm{Na}+\mathrm{K})$ molar ratio reaching over 0.74 . For a specimen length of $17 \mathrm{~cm}$, the alkali content already exceeded 2.0 $\mathrm{kg} / \mathrm{m}^{3} 8.5 \mathrm{~cm}$ from the anode, with the $\mathrm{Li} /(\mathrm{Na}+\mathrm{K})$ molar ratio not yet reaching 0.74 . For specimens with lengths over and including $20 \mathrm{~cm}$, the internal free-state alkali content exceeded $2.0 \mathrm{~kg} / \mathrm{m}^{3}$, with the free-state alkali content near the cathode even exceeding the original designed total amount, with the $\mathrm{Li} /(\mathrm{Na}+\mathrm{K})$ molar ratio not yet reaching 0.74 .

\section{REFERENCES}

1. Andrade, C., "Calculation of chloride diffusion coefficients in concrete from ionic migration measurements," Cement and Concrete Research, Vol. 23, pp. 724-742 (1993).

2. Chen, D. Y., Fundamental Study Using Electrochemical Technique to Inhibit AAR, Master Thesis, Department of Civil Engineering, National Central University, ChungLi, Taiwan (1999). (in Chinese)

3. Folliard, K. J., Thomas, M. D. A., Ideker, J. H., East, B., and Fournier, B., "Case studies of treating ASR-affected structures with lithium nitrate," Proceedings of the $13^{\text {th }}$ International Conference on Alkali-Aggregate Reaction in Concrete, Trondheim, Norway, pp. $90-99$ (2008).

4. Hobbs, D. W., Expansion of Concrete Due to Alkali-Silica Reaction, The Structural Engineer, Cement, Concrete, and Aggregate, England (1984).

5. Kropp, J. and Hilsdorf, H. K., Performance Criteria for Concrete Durability, E \& FN SPON, London (1995).

6. Liu, C. C., Identify the Reactivity of Aggregates in Taiwan and Using Electrochemical Techniques to Mitigate Expansion Due to AlkaliAggregate Reaction in Concrete, Ph.D. Dissertation, Department of Civil Engineering, National Central University, ChungLi, Taiwan (2003). (in Chinese)

7. Michael, D. A., Thomas, B. F., Kevin, J. F., Jason, H. I., and Yadhira, R., The Use of Lithium to Prevent or Mitigate Alkali-Silica Reaction in Concrete Pavements and Structures, Federal Highway Administration, U.S. Department Transportatio, FHWA-HRT-06-133 (2007).

8. Page, C. L. and Yu, S. W., "Potential effects of electrochemical desalination of concrete on alkali-silica reaction," Magazine of Concrete Research, Vol. 47, No. 170, pp. 23-31 (1995).

9. Stokes, D. B., "Use of lithium to combat alkali silica reactivity," Proceeding of the $10^{\text {th }}$ International Conference on Alkali-Aggregate Reaction, Melbourne, Australia, pp. 862-867 (1996).

10. Tang, L., "Electrically accelerated methods for determining chloride diffusivity in concrete - current development," Magazine of Concrete Research, Vol. 48, No. 176, pp. 173-179 (1996).

11. Wang, W. C., A Study of Using One Dimensional Electrochemical Cation Migration Technique to Inhibit Concrete ASR, Ph.D. Dissertation, Department of Civil Engineering, National Central University, ChungLi, Taiwan (2010). (in Chinese)

12. Whitmore, D. and Abbott, S., "Use of an applied electric field to drive lithium ions into alkali-silica reactive structures," Proceeding of the $11^{\text {th }}$ International Conference on Alkali-Aggregate Reaction, Quebec, Canada, pp. 1089-1098 (2000).

13. Wu, S. C., Accelerate Lithium Migration Technique on the Rebar and the Bond Strength, Master Thesis, Department of Civil Engineering, National Central University, ChungLi, Taiwan (2010). (in Chinese)

14. Yang, C. C. and Chiang, C. T., "On the relationship between pore structure and charge passed from RCPT in mineral-free cement-based materials," Materials Chemistry and Physics, Vol. 93, No. 1, pp. 202-207 (2005). 